\title{
Effectiveness of recombinant Escherichia coli on the production of $(R)-(+)$-perillyl alcohol
}

\author{
Chao Sun ${ }^{1,2}$, Xianjuan Dong ${ }^{2}$, Rubing Zhang ${ }^{2^{*}}$ and Congxia Xie 1* $^{*}$
}

\begin{abstract}
Background: $(R)-(+)$-perillyl alcohol is a naturally oxygenated monoterpene widely used as the natural flavor additives, insecticides, jet fuels and anti-cancer therapies. It was also readily available monoterpene precursors. However, this natural product is present at low concentrations from plant sources which are not economically viable. Therefore, alternative microbial production methods are rapidly emerging as an attractive alternative to make $(R)-(+)$-perillyl alcohol production more sustainable and environmentally friendly.

Results: We engineered Escherichia coli to possess a heterologous mevalonate (MVA) pathway, including limonene synthase, P-cymene monoxygenase hydroxylase and P-cymene monoxygenase reductase for the production of $(R)$ $(+)$-perillyl alcohol. The concentration of $(R)-(+)$-limonene (the monoterpene precursor to $(R)-(+)$-perillyl alcohol) reached $45 \mathrm{mg} / \mathrm{L}$ from glucose. Enhanced $(R)-(+)$-perillyl alcohol production was therefore achieved. The strain produced $(R)-(+)$-perillyl alcohol at a titer of $87 \mathrm{mg} / \mathrm{L}$ and a yield of $1.5 \mathrm{mg} / \mathrm{g}$ glucose in a $5 \mathrm{~L}$ bioreactor fed batch system.
\end{abstract}

Conclusions: These datas highlight the efficient production of (R)-(+)-perillyl alcohol through the mevalonate pathway from glucose. This method serves as a platform for the future production of other monoterpenes.

Keywords: Limonene, Perillyl alcohol, Escherichia coli, Mevalonate pathway, Microbial production

\section{Background}

Perillyl alcohol is a natural monoterpene that exists in two optical forms. $(R)-(+)$-perillyl alcohol is produced in perilla leaves, citrus, lemon and lavender [1-3] and has extensive applications. It serves as a natural flavor additive for food, as an insecticide in agricultural fields, as a jet fuel in aviation fields, and as a healing agent for anti-cancer therapeutics [4-7]. The bioconversion of readily available monoterpene precursors (such as $(R)-(+)$-limonene) are

\footnotetext{
*Correspondence: zhangrb@qibebt.ac.cn; xiecongxia@126.com

${ }^{2}$ CAS Key Laboratory of Bio-based Materials, Qingdao Institute of Bioenergy and Bioprocess Technology, Chinese Academy of Sciences, 189 Songling Rd., Qingdao 266101, China

${ }^{1}$ A State Key Laboratory Base of Eco-Chemical Engineering, College of Chemistry and Molecular Engineering, Qingdao University of Science and Technology, 53 Zhengzhou Rd., Qingdao 266042, China
}

recognized as valuable oxygenated derivatives [8]. Up to $70-97 \%$ of $(R)-(+)$-limonene is present in citrus oils [9], produced to levels that exceed $60,000 \mathrm{t}$ per year [10]. Many terpenes are synthesized from limonene, such as perillyl alcohol, carvone and $\alpha$-terpineol. The enantiomers of carvone cost US \$ 30-60 per kg; whilst (S)-(-)- and $(R)-(+)$-perillyl alcohol cost US $\$ 4500 / \mathrm{kg}[7,11]$. As the chemical synthesis of perillyl alcohol is of high cost and leads to environmental pollution, the biosynthesis of perillyl alcohol from renewable carbon sources is regarded as an economically feasible industrial process. New and more effective synthesis procedures are however required.

$(R)-(+)$-perillyl alcohol can be synthesized in Escherichia coli [12], Pseudomonas putida [5, 13-16], Mortierella minutissima [17], Fusarium verticilloides [18], Aspergillus strain $[19,20]$ from the biotransformation of

(c) The Author(s). 2021 Open Access This article is licensed under a Creative Commons Attribution 4.0 International License, which permits use, sharing, adaptation, distribution and reproduction in any medium or format, as long as you give appropriate credit to the original author(s) and the source, provide a link to the Creative Commons licence, and indicate if changes were made. The images or other third party material in this article are included in the article's Creative Commons licence, unless indicated otherwise in a credit line to the material. If material is not included in the article's Creative Commons licence and your intended use is not permitted by statutory regulation or exceeds the permitted use, you will need to obtain permission directly from the copyright holder. To view a copy of this licence, visit http://creativecommons.org/licenses/by/4.0/ The Creative Commons Public Domain Dedication waiver (http://creativecommons.org/publicdomain/zero/1.0/) applies to the data made available in this article, unless otherwise stated in a credit line to the data. 
Table 1 Biosynthesis of (R)-(+)-perillyl alcohol I by microbial transformation

\begin{tabular}{|c|c|c|c|c|c|c|c|}
\hline Host & $\begin{array}{l}\text { Stereo } \\
\text { isomer }\end{array}$ & Product & Titers & Yield & Carbon source and cultivations & $\begin{array}{l}\text { Recovery } \\
\text { method }\end{array}$ & Reference \\
\hline Escherichia coli & $(+)$ & $\begin{array}{l}\text { perillyl } \\
\text { alcohol }\end{array}$ & $\begin{array}{l}0.51 \mathrm{mg} / \\
\mathrm{L}\end{array}$ & NA & $\begin{array}{l}\text { Glucose, }(R)-(+) \text {-limonene, sh-ake } \\
\text { flask }(24 \mathrm{~h})\end{array}$ & $\begin{array}{l}\text { Closed culture } \\
\text { flask }\end{array}$ & {$[12,21]$} \\
\hline $\begin{array}{l}\text { Pseudomonas taiwanensis } \\
\text { VLB120DC }\end{array}$ & $(+)$ & $\begin{array}{l}\text { perillyl } \\
\text { alcohol }\end{array}$ & NA & $\begin{array}{l}\text { 100umol/ } \\
g_{c d w}\end{array}$ & $(R)-(+)$-limonene, shake flask (1 h) & $\begin{array}{l}\text { Closed culture } \\
\text { flask }\end{array}$ & {$[15]$} \\
\hline Aspergillus cellulosae M-77 & $(+)$ & $\begin{array}{l}\text { perillyl } \\
\text { alcohol }\end{array}$ & NA & NA & $(R)-(+)-$ limonene, shake flask & $\begin{array}{l}\text { Closed culture } \\
\text { flask }\end{array}$ & [20] \\
\hline Mortierella minutissima 01 & $(+)$ & $\begin{array}{l}\text { perillyl } \\
\text { alcohol }\end{array}$ & $\begin{array}{l}258.1 \\
\mathrm{mg} / \mathrm{L}\end{array}$ & NA & $(R)-(+)-$ limonene, shake flask (72 h) & $\begin{array}{l}\text { Closed culture } \\
\text { flask }\end{array}$ & [17] \\
\hline
\end{tabular}

$(R)-(+)$-limonene to $(R)-(+)$-perillyl alcohol (Table. 1). The recombinant Pseudomonas taiwanensis VLB120 harboring cymAa and cymAb from Pseudomonas putida can convert $(R)-(+)$-limonene to $(R)-(+)$ - perillic alcohol [15] (Table 1). The maximum yield of $(R)-(+)$-perillyl alcohol was $258.1 \mathrm{mg} / \mathrm{L}$ for 3 days using Mortierella minutissima cultivation containing $0.5 \%(R)-(+)$-limonene at $15^{\circ} \mathrm{C}$ [17]. This produced the highest levels of $(R)$ $(+)$-perillyl alcohol currently reported. It should be as a substrate for the above microbial transformation reaction, but the raw materials were not easily obtained [22]. Metabolic engineering for natural compound production can be enhanced through gene modifications that increase enzyme activity. Many terpenoids have been

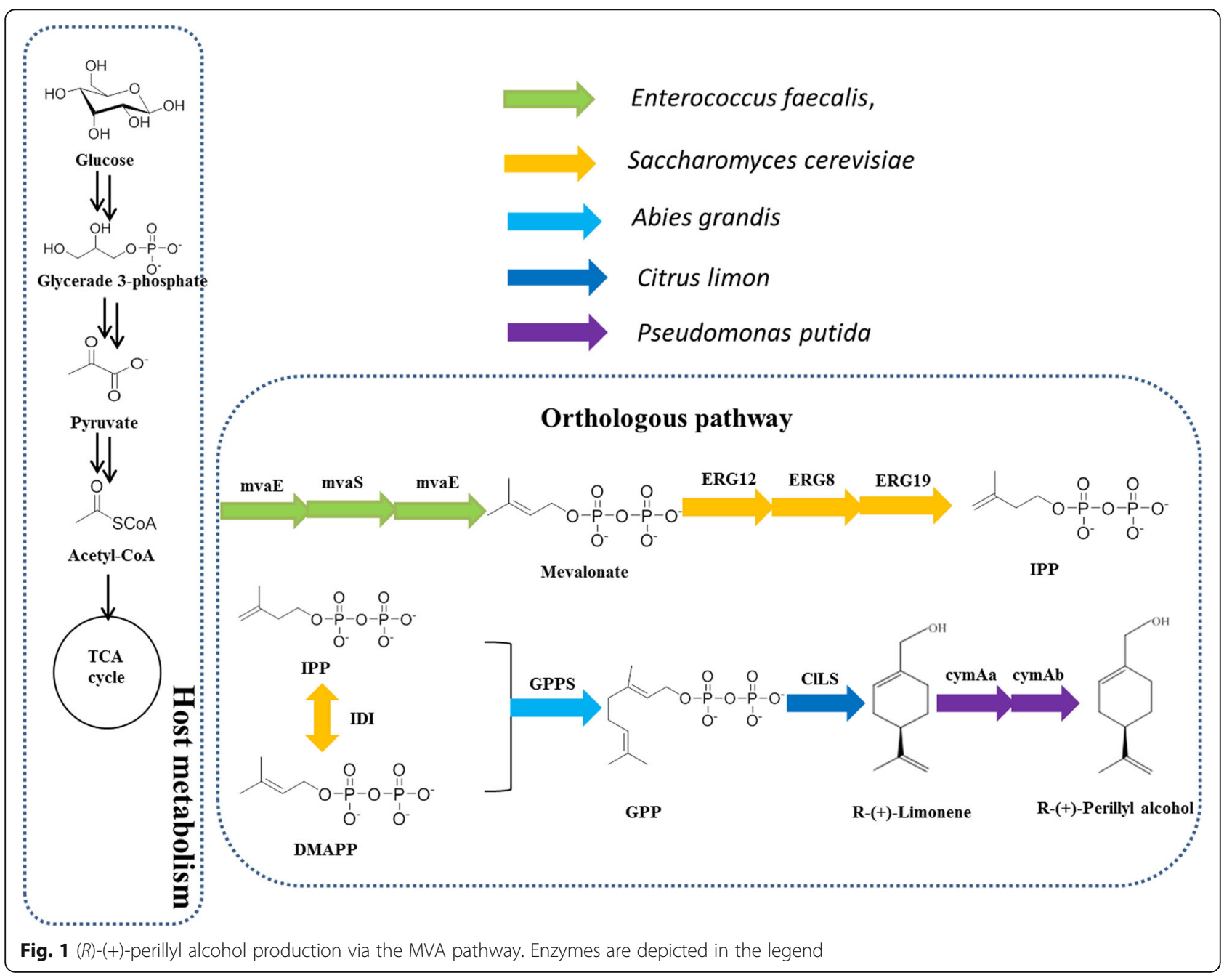


produced at high titers by metabolic engineering, including monoterpenes, sesquiterpenes, diterpenes and tetraterpenes [23-29].

Isopentenyldiphosphate (IPP) and its isomer dimethylallyl diphosphate (DMAPP) form the building blocks of monoterpenes, sesquiterpenes and diterpenes during synthesis, the precursors of which include geranyl pyrophosphate (GPP), farnesylpyrophosphate (FPP), and geranylgeranyl pyrophosphate (GGPP), respectively. These precursors are derived from mevalonate (MVA) and are catalyzed by geranyl pyrophosphate diphosphate synthase (GPPS) (Fig. 1). However, the microbial mediated production of monoterpenes is limited by toxicity [29] and poor GPPS expression [30,31]. In this study, we initially engineered $E$. coli to produce $(R)-(+)$-perillyl alcohol from glucose by the heterologous expression of $\mathrm{P}$ cymene monoxygenase hydroxylase (CymAa) and a Pcymene monoxygenase reductase (CymAb) (Fig. 1). Genetic modifications to enhance the production of $(R)$ $(+)$-perillyl alcohol were also performed. These included the codon optimization of cymAa, cymAb and ClLS and exogenous GPPS expression. The highest performing strain SC04 was then cultured under fed-batch conditions for the assessment of its potential for largescale production.

\section{Results}

\section{Perillyl alcohol production from limonene}

It is well established that during (S)-(-)-perillyl alcohol production, titers can be increased by $100 \mathrm{mg} / \mathrm{L}$ using Escherichia coli [32]. Many terpenoids have been produced to high titers through metabolic engineering, including monoterpenes, sesquiterpenes, diterpenes and tetraterpenes. Limonene hydroxylase from Bacillus stearothermophilus BR 388 (LHBS), was proved to produce $(R)-(+)$ - perillyl alcohol $0.51 \mathrm{mg} / \mathrm{L}$ with the substrate $(R)-(+)$-limonene $[12,21]$. LHBS was ligated into pET28a $(+)$ to create pSC00, meanwhile, cymAa and $c y m A b$ were created pSC01 in Table S1. Limonene is toxic to most microorganisms and its concentrations regulate the growth of BL21 (DE3). It was therefore important to assess the optimal concentrations of limonene for fed-batch production. Different $(R)-(+)$-limonene concentrations were assessed $(0.2 \mathrm{mM}$ to $3.0 \mathrm{mM})$ in growth assays. With the increasing of $(R)-(+)$-limonene concentration, cell growth was inhibited. At $(R)$ -

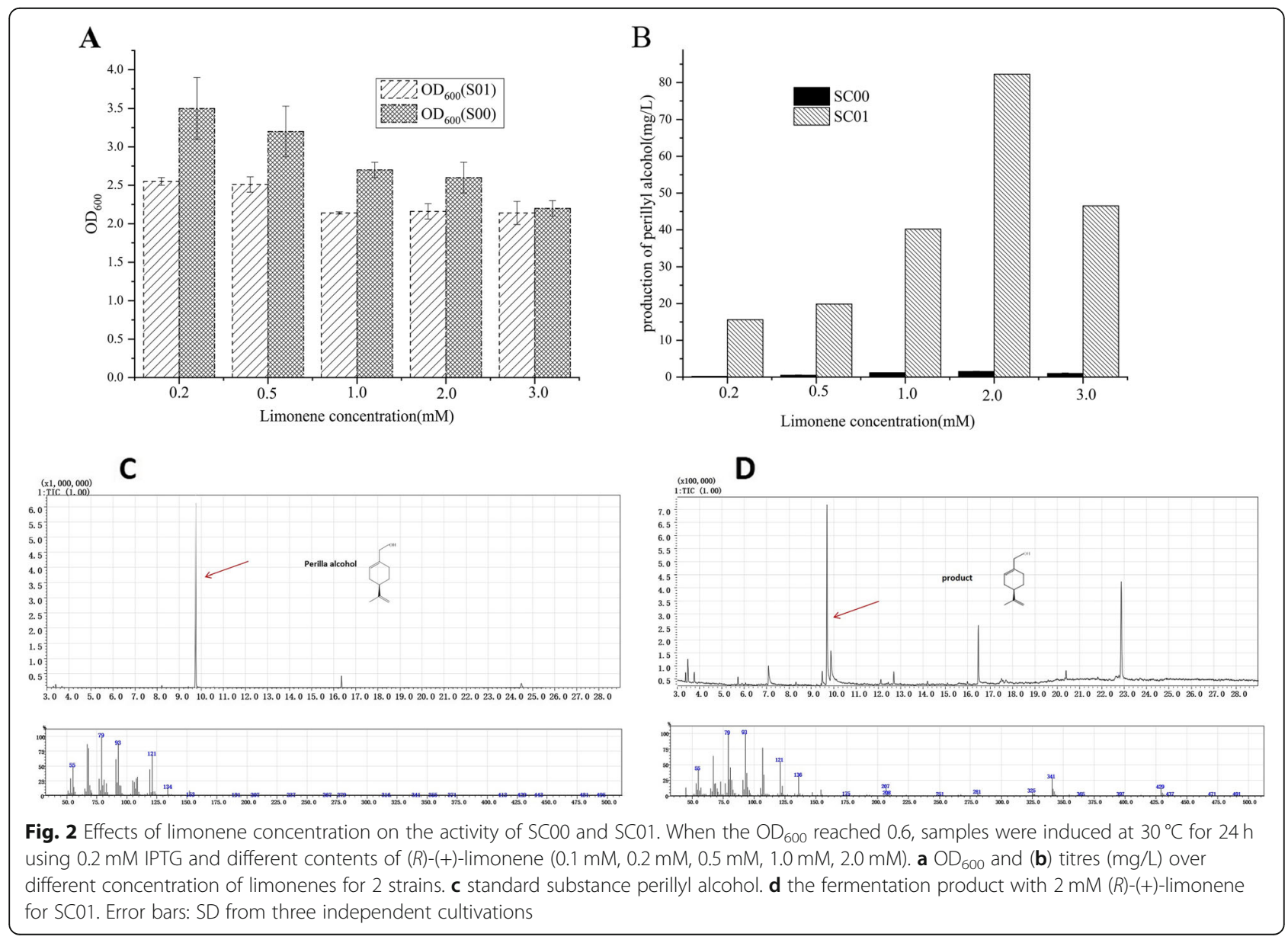


(+)-limonene concentrations of $1.0 \mathrm{mM}$, the $\mathrm{OD}_{600}$ decreased from 2.5 to 2.0 for SC01 (Fig. 2a). When $(R)$ $(+)$-limonene was used at $2 \mathrm{mM}$, the maximum production was $86.9 \mathrm{mg} / \mathrm{L}$ and the conversion yield of perillyl alcohol was 30\% for SC01 (Fig. 2b). For another strain $\mathrm{SC} 00$, it produced the low concentration of $1.5 \mathrm{mg} / \mathrm{L}$, and cell growth was suppressed (Fig. 2b). In the later study, the strain SC01 was used as the research basis.

Products were identified by GC-MS after organic extraction by ethyl acetate. As shown in Fig. 2c and d, control assays with extracts of $E$. coli lacking a cDNA clone did not yield $(R)-(+)$-perillyl alcohol, whilst $E$. coli carrying cymAa and cymAb from Pseudomonas putida produced $(R)-(+)$-perillyl alcohol to detectable quantities. The biosynthetic pathway for $(R)-(+)$-perillyl alcohol production was successfully constructed using $(R)$ $(+)$-limonene as a substrate.

\section{Limonene production from glucose}

We optimized the yields of limonene to improve the production of perillyl alcohol. pTrcHis2B and pET-28a (+) were assessed. pYJM14 contains ERG8, ERG19, IDI from Saccharomyces cerevisiae [33]. pSC02 contains geranyl pyrophosphate synthase GPPS from Abies grandis that converts IPP/DMAPP to GPP, and $(R)-(+)$-limonene synthase CILS from Citrus limon that converts GPP to limonene [34] (Table S1). SC02 was cultured in fermentation medium under sealed shake-flask conditions.

The levels of $(R)-(+)$ limonene in the culture media were plotted against known concentrations of $(R)$ $(+)$-limonene. The $(R)-(+)$-limonene concentration of SC02 reached $38 \mathrm{mg} / \mathrm{L}$ and $45 \mathrm{mg} / \mathrm{L}(\mathrm{mg}$ limonene per liter of culture, the same as follows) with $0.2 \mathrm{mM}$ IPTG and $10 \% \mathrm{n}$-dodecane overlay at $24 \mathrm{~h}$ and $48 \mathrm{~h}$ of induction. When 10\% DINP (diisononyl phthalate) was used instead of the $\mathrm{n}$-dodecane overlay, the limonene titers were $29 \mathrm{mg} / \mathrm{L}$ and $40 \mathrm{mg} / \mathrm{L}$ respectively at $24 \mathrm{~h}$ and $48 \mathrm{~h}$ (Fig. 3c). The enantiomer forms produced by the strain cultures were analyzed using GC with a Cyclosil-B column, and the production of $(R)-(+)$-limonene by $\mathrm{SC} 02$ was confirmed (Fig. 3a and b).

\section{Microbial perillyl alcohol production using the MVA pathway}

CymAa and CymAb catalyze the biosynthesis of $(R)-(+)$ perillyl alcohol using $(R)-(+)$ limonene as a direct substrate through a hydroxylated reaction at the 7 position. We cloned cymAa and cymAb from Pseudomonas
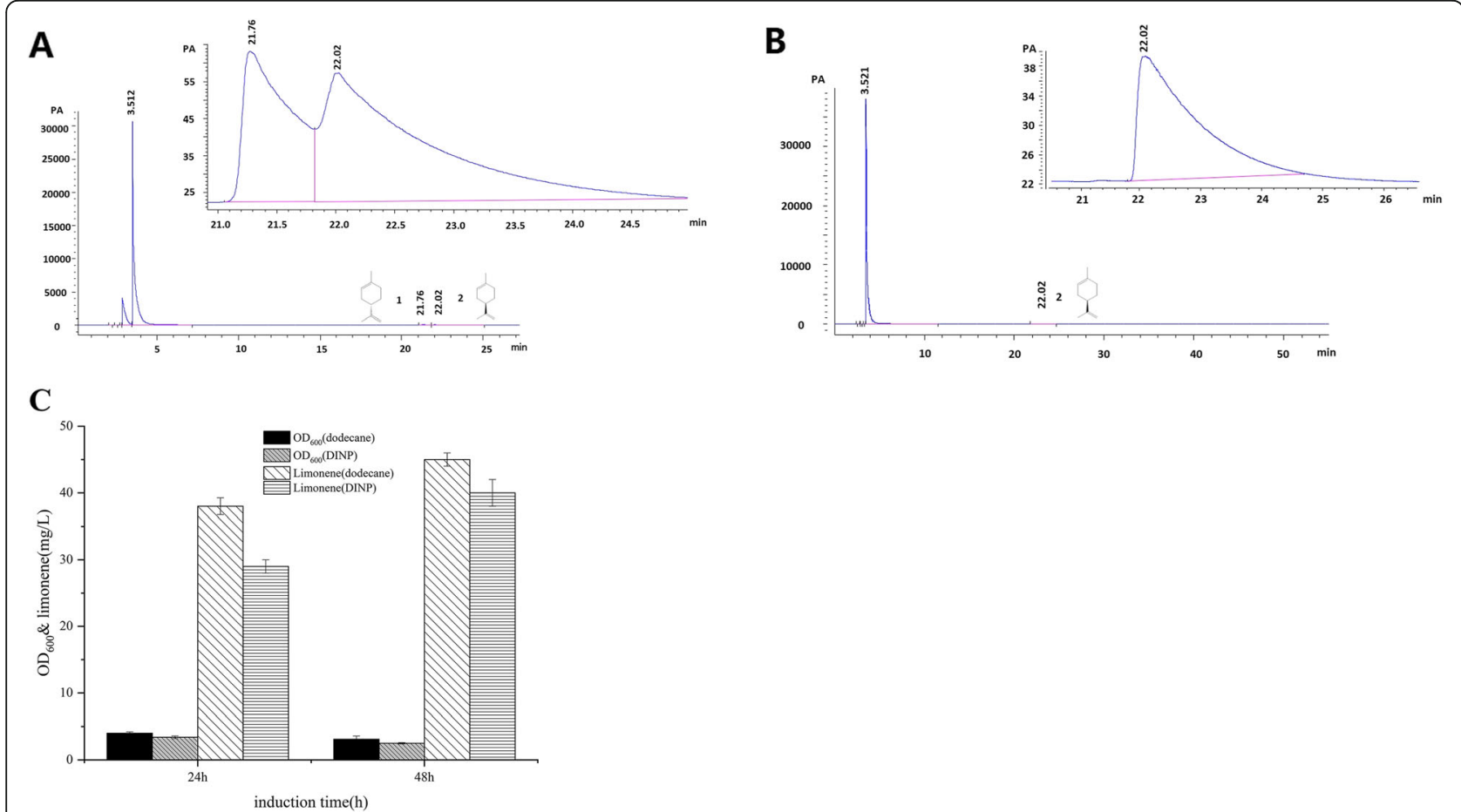

Fig. 3 Limonene production using the SC02 strain. a The enantiomeric distribution of limonene was analyzed using the Agilent Technologies 7890B GC System on a Cyclodex B column $(30 \mathrm{~m} \times 0.25 \mathrm{~mm}$ internal diameter; film thickness $=0.25 \mu \mathrm{m})$. GC conditions were as follows: $50^{\circ} \mathrm{C}$ hold, $2^{\circ} \mathrm{C} / \mathrm{min}$ ramping to $160^{\circ} \mathrm{C}$; carrier: high-purity helium, linear velocity: $1 \mathrm{ml} / \mathrm{min}$; temperature of the injector: $250^{\circ} \mathrm{C}$; split ratio: $1: 20$. Compounds of interest: (S)-(-)-limonene at $21.2 \mathrm{~min}$ and $(R)-(+)$-limonene at $22.02 \mathrm{~min}$. b The fermentation broth was mixed and centrifuged, and the organic layer was analyzed. c The total production of Limonene was measured after $24 \mathrm{~h}$ and $48 \mathrm{~h}$ of IPTG induction and $10 \% \mathrm{n}$-dodecane or DINP induction 


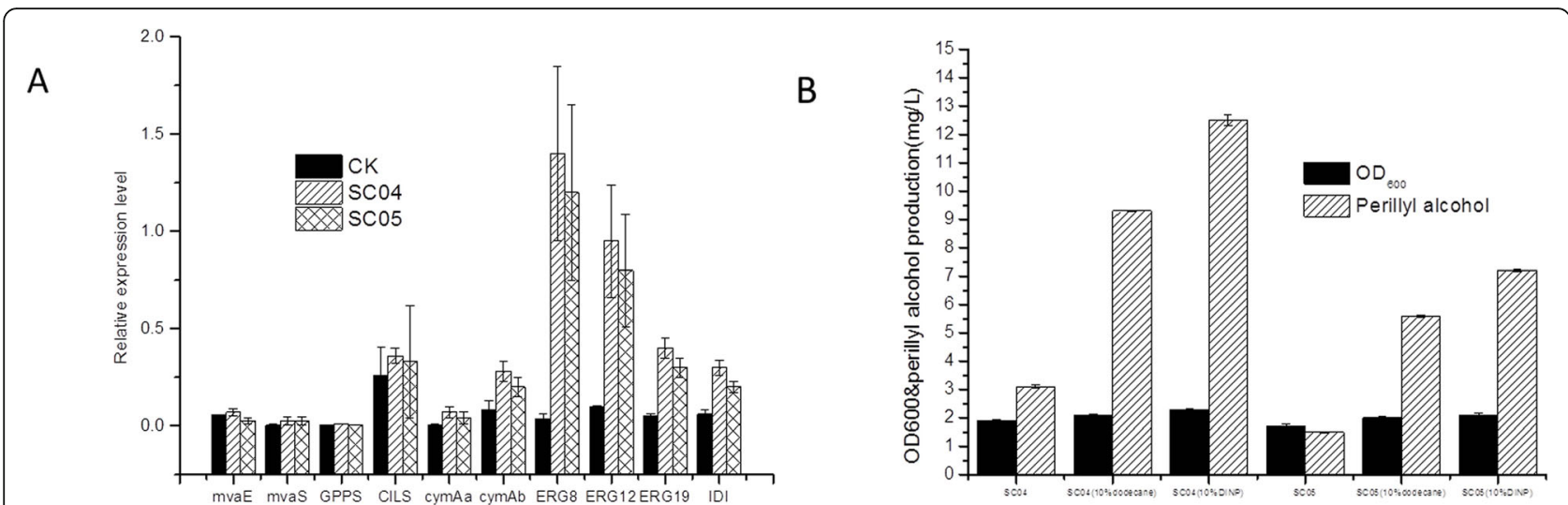

Fig. 4 (R)-(+)-Perillyl alcohol production using SC04 and SC05 strains. a relative expression levels in SC04 and SC05 engineered for (R)-(+)-perillyl alcohol production. Data was for $24 \mathrm{~h}$ in LB medium with $0.2 \mathrm{mM} \mathrm{IPTG}$ and $20 \mathrm{~g} / \mathrm{L}$ glucose. Gene expression was calculated using the $2^{-\Delta \Delta C T}$. system and are shown as the mean $\pm \mathrm{SD}(n \geq 3)$. Identical letters indicate no significant differences $(p<0.05)$. (5) Total production of $(R)$ - $(+)$-perillyl alcohol was measured at $48 \mathrm{~h}$ after induction with $0.2 \mathrm{mM} \mathrm{IPTG}$ and10\% n-dodecane or 10\% DINP, Data are the means of 3 repetitions \pm SD

putida into pSC04\&pSC05. Terpenoid synthase is expressed to low levels in E. coli [35], so cymAa and $c y m A b$ were codon optimized (Table S1). According to the analysis of chirality of the intermediate limonene produced by $\mathrm{SC02}$, we concluded that the configuration of perillyl alcohol was $R$-type (Fig. $3 \mathrm{~b}$ ). Expression levels in the perillyl alcohol pathway for $\mathrm{SC0} 4$ were investigated by qRT-PCR. The results indicated that ERG8, ERG19 ERG12, and IDI significantly increase compared to the control. Moreover, changes in the expression of mvaE, mvaS, CILS, GPPS, cymAa and cymAb were comparable to the control (Fig. 4a). We used n-dodecane or DINP as the extraction solvent and the organic phase was collected and centrifuged to remove cell contaminants. Samples were then subjected to GC-MS analysis and trace levels of perillyl alcohol were detected. pYJM14 and pSC04\&pSC05 were co-transformed into $E$. coli BL21 (DE3), resulting in recombinant strain SC04\&SC05. SC04 that was cultured in sealed shake flasks to assess perillyl alcohol production. The fermentation broth of the strain SC04 was extracted by ethyl acetate, TLC, product refined and optical rotation detection. The specific rotation value of the product was $[\alpha]_{\mathrm{D}}^{20}=+82 \pm 1 \quad\left(\mathrm{C} 1.8, \mathrm{CHCl}_{3}\right)$, the standard was $[\alpha]_{\mathrm{D}}^{20}=+84\left(\mathrm{C} 1.8, \mathrm{CHCl}_{3}\right)[36]$. From the above, the fermentation product can be identified as $(R)-(+)$-perillyl alcohol.

The $(R)-(+)$-perillyl alcohol levels for SC04 reached $12.5 \mathrm{mg} / \mathrm{L}$ after induction by $0.2 \mathrm{mM}$ IPTG and $10 \%$ DINP overlay for $48 \mathrm{~h}$, which was 2.4-fold higher than SC05 $(7.2 \mathrm{mg} / \mathrm{L}$ for $48 \mathrm{~h}$ ) (Fig. 4b). In the absence of DINP, SC04 and SC05 produced $3.1 \mathrm{mg} / \mathrm{L}$ and $1.5 \mathrm{mg} / \mathrm{L}$ of $(R)-(+)$-perillyl alcohol. We included n-dodecane overlays in the cultures, and thus a small amount of perillyl alcohol was detected [32]. The production of $(R)$ (+)-perillyl alcohol was $9.3 \mathrm{mg} / \mathrm{L}$ in $\mathrm{SC} 04$ and $5.6 \mathrm{mg} / \mathrm{L}$ in SC05, mainly due to the rapid extraction of limonene to the organic phase, and as n-dodecane overlay could not be used for perillyl alcohol fermentation. In the SC04, the production of $(R)-(+)$ - perillyl alcohol and mevalonate was $12.5 \mathrm{mg} / \mathrm{L}$ and $102 \mathrm{mg} / \mathrm{L}$ after $48 \mathrm{~h}$ of induction (BL21 (DE3)/pET-28a(+) not detected, Fig. $\mathrm{S} 1)$. So, the production of $(R)-(+)$-perillyl alcohol was through the mevalonate pathway from glucose.

\section{Fed-batch culture of engineered E.coli strains}

High cell densities for $(R)-(+)$-perillyl alcohol production were achieved through fed-batch fermentation using SC04 in a $5 \mathrm{~L}$ bioreactor. According to the residual glucose concentrations, feeding rates were maintained at $\leq 1 \mathrm{~g} / \mathrm{L}$. Figure 5 shows the time-course of $(R)-(+)$-perillyl alcohol production and cell density during fermentation. $(R)-(+)$-perillyl alcohol biosynthesis was initiated from 5 $\mathrm{h}$ of induction and 10\% DINP was added during the fedbatch process. After $36 \mathrm{~h}$ of induction, the production of

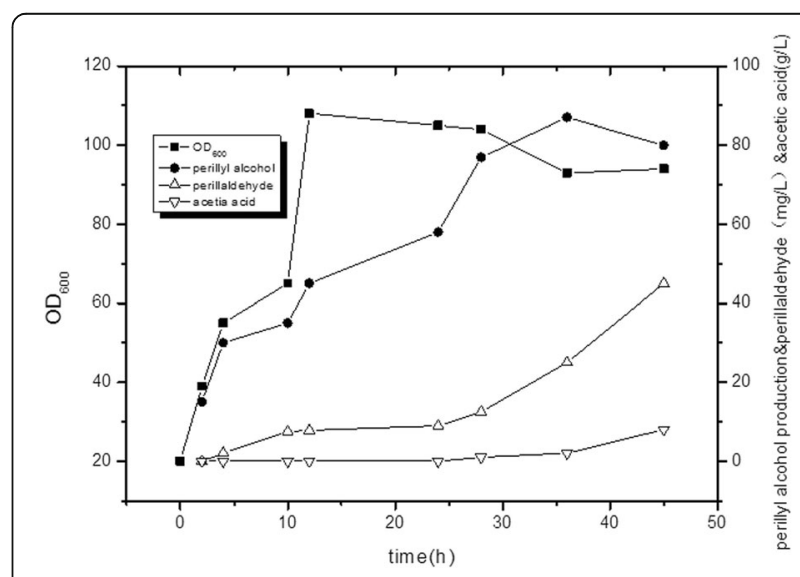

Fig. 5 Time-course of (R)-(+)-perillyl alcohol production during fedbatch fermentation of SCO4 
$(R)-(+)$-perillyl alcohol peaked at $87 \mathrm{mg} / \mathrm{L}$ with DINP overlay and the yield was $1.5 \mathrm{mg} / \mathrm{g}$ glucose. The theoretical conversion yield of $(R)-(+)$-perillyl alcohol from glucose is $28.1 \%$ (1.5 glucose $0.5(R)-(+)$-perillyl alcohol) However, the engineered strain achieved a cell-density $\mathrm{OD}_{600}$ of 108 for two-phase fermentation. In the late fermentation stage, the content of perillyl aldehyde and acetic acid increased to $45 \mathrm{mg} / \mathrm{L}$ and $8 \mathrm{~g} / \mathrm{L}$ respectively, which hindered the production of $(R)-(+)$-perillyl alcohol [37]. The accumulation of IPP and DMAPP may have influenced the growth of the engineered strain [25, 38, 39]. However, the two-phase fermentation of $(R)$ $(+)$-perillyl alcohol fermentation eliminated toxic intermediates. $(R)-(+)$-perillyl alcohol biosynthesis requires many overexpressed genes, which influence host cell viability and reduce productivity [40].

\section{Discussion}

$(R)-(+)$-perillyl alcohol is produced in perilla leaves, citrus, lemon and lavender and has a range of applications. Many terpenes are synthesized from limonene, such as perillyl alcohol, carvone and $\alpha$-terpineol. As the chemical synthesis of perillyl alcohol is of high cost and is environmentally unfriendly, the biosynthesis of perillyl alcohol from renewable carbon sources is regarded as an economically feasible industrial process. Indeed, the development of $(R)-(+)$-perillyl alcohol as an anti-cancer drug has been limited by the costs associated with extracting the compound from its natural oil. Terpenes are produced by microorganisms and can be scaled-up to increase drug production [41]. We used E.coli as a host and confirmed the feasibility of $(R)-(+)$-perillyl alcohol production. The levels produced were however, too low for industrial requirements.

Through comparison of strain SC00 and SC01, we found that SC00 by expressed LHBS from Bacillus stearothermophilus BR 388 produced a little, $1.5 \mathrm{mg} / \mathrm{L}$ (Fig. $2 \mathrm{~b})$, It may be that cofactors (NADPH, ATP) are involved in the fermentation process, which reported the production of $0.51 \mathrm{mg} /$ Lwith $(R)-(+)$-limonene substrate [21]. so we directly selected the cymAa and cymAb which convert limonene derived from the metabolism of $p$-cymene [15]. Enzyme activity was lower than other terpene synthases, that reduce perillaldehyde or perillic acid [15]. We initially engineered SC02 and showed successful $(R)-(+)$-perillyl alcohol production using GC-MS (Fig. 2d). The maximum production of $(R)-(+)$-perillyl alcohol composed with $(R)-(+)$-limonene as substrate was $86.9 \mathrm{mg} / \mathrm{L}$ and lethal concentrations of limonene to E. coli were $2 \mathrm{mM}$ (Fig. 2b). (R)-(+)-Limonene accumulates in biological membranes leading to damage. The compound is also insoluble in water [42]. It has been reported that limonene is inhibitory to multiple microorganisms [43]. A recent report revealed that $0.025 \%(\mathrm{v} / \mathrm{v})$ limonene inhibited the growth of E. coli [44]. Thus, the tolerance and solubility of limonene requires improvement to increase both the concentrations and yields of $(R)-(+)$-perillyl alcohol.

In previous studies, terpenoids have been studied using the MVA pathway [23, 25, 26, 45]. Our research group constructed engineered E.coli which synthesized isoprene by the mevalonate (MVA) pathway, and produced isoprene to $665.2 \mathrm{mg} / \mathrm{L}$ under flask conditions [46, 47]. GPPS and CILS were engineered to improve $(R)-(+)$-limonene production, and $\mathrm{SC0} 3$ produced no detectable limonene (data not shown), highlighting the need for terpenes. When no extracts were added during limonene fermentation, no detectable SC02 was observed (data not known), indicating that limonene is rapidly lost from the culture medium. As limonene from the fermentation system was highly volatile and anti-microbial [48, 49] other collection methods have been reported including culture extraction, solvent overlay, solid-phase microextraction, gas shipping to a cold trap, and adsorbent polydimethlsiloxane bars $[48,50,51]$. Whilst not all of these methods are appropriate, they do prevent product inhibition and toxicity, avoiding evaporative loss of the limonene product using the two-phase system. Davies et al. [52] showed that an overlay of n-dodecane enhanced limonene recovery. $\mathrm{N}$-dodecane was selected as a favorable solvent for terpenoid extraction experiments due to its low volatility [52]. In engineered E.coli, DINP fermentation prolongs both the growth and production phases, leading to (S)-(-)-limonene concentrations of $1.35 \mathrm{~g} / \mathrm{L}$ [53]. $(R)-(+)$-limonene obtained by $\mathrm{n}$-dodecane extraction was $45 \mathrm{mg} / \mathrm{L}$ for $48 \mathrm{~h}$ (Fig. 3c). It may be that the distribution coefficient of $(R)-(+)$-limonene in $\mathrm{n}$ octane is larger than that of the DINP phase. The strain fermented by the DINP overlay also inhibited cell growth, and the $\mathrm{OD}_{600}$ decreased from 3.4 to 2.5 (Fig. 3c). Jongedijk et al. [48] engineered Saccharomyces cerevisiae to express $(R)-(+)$-limonene synthase from Citrus limon. Trapping of the headspace in limonene synthase expressing strains resulted in $0.12 \mathrm{mg} / \mathrm{L}(R)-(+)$-limonene. Pang et al. [54] engineered Yarrowia lipolytica to achieve $(R)-(+)$-limonene at $11.705 \mathrm{mg} / \mathrm{L}$, through the overexpression of HMGR and the optimization of the fermentation conditions. Cao et al. [55] engineered Yarrowia lipolytica to increase limonene titers to $23.56 \mathrm{mg} /$ $\mathrm{L}$ by encoding neryl diphosphate synthase1 (NDPS1) and limonene synthase (LS). Here, we engineered $E$. coli to produce $(R)-(+)$-limonene to $45 \mathrm{mg} / \mathrm{L}$.

We confirmed that the chirality of perillyl alcohol was $(R)$-type in SC04, which was performed with $(R)-(+)$-limonene as an intermediate (Fig. $3 \mathrm{~b})$. We then engineered SC04 \& SC05 and investigated the effects of copy numbers on $(R)-(+)$-perillyl alcohol production. We hypothesized that cymAa and $c y m A b$ genes produced by the 
lower copies of $\mathrm{SC} 05$ could not repress all promoters. In contrast, SC04 had 40 copies encoding the repressor from medium and middle-copy plasmids. The genes contributed to higher levels in SC04 than in $\mathrm{SC0}$ (Fig. 4a). This hypothesis was supported by the production of perillyl alcohol, which was 1.7-fold in SC04 and SC05 (from $7.2 \mathrm{mg} / \mathrm{L}$ to $12.5 \mathrm{mg} / \mathrm{L}$ ) (Fig. $4 \mathrm{~b}$ ). In addition, the levels of ERG12, ERG8, and ERG19 in the MVA pathway were higher than those of the control strain, whilst the levels of GPPS, CILS, cymAa and cymAb showed no obvious changes compared to controls (Fig. 4a). Most intermediates can be efficiently converted to IPP, but the production from IPP to perillyl alcohol was weak. This suggests the enhanced production of $(R)-(+)$-perillyl alcohol through regulating metabolic imbalances.

$(R)-(+)$-perillyl alcohol production was achieved by assembling biosynthetic genes encoding a heterologous MVA pathway. The highest-performing strain (SC04) accumulated up to $87 \mathrm{mg} / \mathrm{L}$ of $(R)-(+)$-perillyl alcohol under fed-batch fermentation conditions. The synthesis of $(R)-(+)$-perillyl alcohol reported in this study has not been systematically optimized. From the perspective of fermentation process (Fig. 5), the low yield of $(R)$ $(+)$-perillyl alcohol depends on two aspects. On the one hand, the by-product perillaaldehyde leads to the decrease of $(R)-(+)$-perillyl alcohol content. It may be due to the presence of alcohol dehydrogenase [56] (such as $y i g \mathrm{~B})$ which can convert geraniol to geranial in E. coli. Therefore, the key gene cymA $a$ and $c y m A b$ were overexpressed and optimized. On the other hand, the fermentation control was optimized to reduce the content of acetic acid [57] and promote cell growth.

\section{Conclusions}

We have engineered $E$. coli to produce $(R)-(+)$-perillyl alcohol from glucose through the MVA pathway. In this study, it was firstly reported that $(R)-(+)$-perillyl alcohol was synthesized from glucose in recombinant Escherichia coli, which produced $87 \mathrm{mg} / \mathrm{L}$ of $(R)-(+)$-perillyl alcohol. It provides new methods for the synthesis of chiral perillyl alcohol. Efforts should now be directed towards the optimization of the MVA pathway.

\section{Methods}

\section{Strains and culture conditions}

Metabolic engineering for natural compound production can be enhanced through gene modifications that increase enzyme activity. All experimental materials used in this study are listed in Table S1. E.coli were grown in $\mathrm{LB}$ (tryptone $10 \mathrm{~g} / \mathrm{L}$, yeast extract $5 \mathrm{~g} / \mathrm{L}$ and $\mathrm{NaCl} 10 \mathrm{~g} /$ $\mathrm{L})$. During the production of $(R)-(+)$-limonene and $(R)$ $(+)$-perillyl alcohol, strains were cultivated in shakeflasks in medium containing glucose $10 \mathrm{~g} / \mathrm{L}, \mathrm{MgSO}_{4} 1$ $\mathrm{mM}$ and riboflavin $0.05 \mathrm{mM}$ during fed-batch fermentation in glucose $20 \mathrm{~g} / \mathrm{L}, \mathrm{K}_{2} \mathrm{HPO}_{4} 9.8 \mathrm{~g} / \mathrm{L}$, ferric ammonium citrate $0.3 \mathrm{~g} / \mathrm{L}$, citric acidmonohydrate $2.1 \mathrm{~g} /$ $\mathrm{L}, \mathrm{MgSO}_{4} 1 \mathrm{mM}$, riboflavin $0.05 \mathrm{mM}$ and $1 \mathrm{~mL}$ trace element solution, including $\left(\mathrm{NH}_{4}\right)_{6} \mathrm{Mo}_{7} \mathrm{O}_{24} .4 \mathrm{H}_{2} \mathrm{O} 0.37 \mathrm{~g} /$ $\mathrm{L}, \mathrm{ZnSO}_{4} .7 \mathrm{H}_{2} \mathrm{O} 0.29 \mathrm{~g} / \mathrm{L}, \mathrm{H}_{3} \mathrm{BO}_{4} 2.47 \mathrm{~g} / \mathrm{L}, \mathrm{CuSO}_{4} .5 \mathrm{H}_{2} \mathrm{O}$ $0.25 \mathrm{~g} / \mathrm{L}$, and $\mathrm{MnCl}_{2} \cdot 4 \mathrm{H}_{2} \mathrm{O} 1.58 \mathrm{~g} / \mathrm{L}$. As required, ampicillin $(100 \mu \mathrm{g} / \mathrm{ml})$ and kanamycin $(50 \mu \mathrm{g} / \mathrm{ml})$ were added for selection.

\section{Plasmid construction}

Limonene hydroxylase (pOT435) gene (LHBS, GenBank Accession No. AF039527.1) from Bacillus stearothermophilus BR 388, were codon optimized and cloned into pUC57. $L H B S$ were PCR amplified and cloned into pET28a (+) with EcoI/XhoI restriction sites, creating pSC00 (pET28a-LHBS). P-cymene monoxygenase hydroxylase (cymAa, GenBank Accession No. AAB62299.1) and P-cymene monoxygenase reductase (cym $A b$, GenBank Accession No.:AAB62300.1) from Pseudomonas putida were codon optimized by BGI, and cloned into pUC57. cymAa and $c y m A b$ were PCR amplified and subcloned into pET28a (+) with BamHI/SacI restriction sites, creating pSC01 (pET28a-cymAa-cymAb). ClLS (GenBank Accession No.:AF514287.1) of Citrus limon and GPPS (GenBank Accession No.:AF513112.1) of Abies grandis were optimized by BGI and synthesized by GeneWiz (Suzhou, China), producing pUC57-ClLS\&pUC57-GPPS. MvaEmvaS was then excised from PYJM20 [46] and ligated into pET-28a $(+)$ to create pET28a-mvaE-mvaS. GPPS and ClLS which were truncated in the $\mathrm{N}$-terminus, were cloned and assembled into pET28a-mvaE-mvaS at the SacI/AatII sites to generate pSC02 (Table S1). CymAa$c y m A b$ fragments were obtained through Pseudomonas putida using AatII and PacI and ligated into pSC02 to create pSC03 (Table S1). MvaE, mvaS, and GPPS were cloned from pSC02 into pCOLADuet-1 at the BamHI/XhoI sites, generating pcolaDuet-mvaE-mvaS-GPPS-CILS. CymAa, cym $A b$ were cloned from pSC03 into pcolaDuet-mvaEmvaS-GPPS-ClLS at the Xhol/PacI sites to produce pSC05 (Table S1).

pYJM14 was constructed from pTrcHis2B through the introduction of ERG8, ERG12, ERG19 and IDI from $S$. cerevisiae $[33,58]$. All plasmids and primers are shown in Table S2.

\section{RT-PCR analysis}

Total RNA was isolated from $24 \mathrm{~h}$ cultures using commercially available SPAKeasy RNA kits. RNA was reverse transcribed using TaKaRa Primer Script RT reagent Kit and RT-PCRs were performed. Each reaction contained $1 \mu \mathrm{L}$ cDNA, $5 \mu \mathrm{L}$ TB green Premix Ex TaqII, $0.2 \mu \mathrm{L} 50 \times$ ROX Reference Dye, $0.2 \mu \mathrm{M}$ for/rev primer, and $\mathrm{dd}_{2} \mathrm{O}$ up to $10 \mu \mathrm{l}$. RT-PCR conditions were as follows: $30 \mathrm{~s}$ at $95^{\circ} \mathrm{C}, 40$ cycles of $95^{\circ} \mathrm{C}$ for $5 \mathrm{~s}, 60^{\circ} \mathrm{C}$ for 30 
s. Gene expression was normalized to the absolute transcript levels of rpoD. qRT-PCRs were performed on a Primer 5.0 program (Table S3). Relative gene expression was calculated using the $2^{\Delta \Delta} \mathrm{Ct}$ method for each treatment. Reactions were repeated a minimum of 3 times.

\section{Shake-flask fermentation}

Cultures were produced in in $25 \mathrm{ml}$ of LB. E. coli strains with each recombinant plasmid inoculated in a gyratory shaker at $37^{\circ} \mathrm{C}$ and $180 \mathrm{rpm}$. IPTG $(0.2 \mathrm{mM})$ was added to induce recombinant protein expression upon an $\mathrm{OD}_{600}$ of 0.6. Cultures were incubated at $30^{\circ} \mathrm{C}$ with 2phase fermentation [59] used for limonene and perillyl alcohol extraction from the aqueous broth due to the toxicity of terpenes. We added $10 \%(\mathrm{v} / \mathrm{v}) \mathrm{n}$-dodecane or DINP (disononyl phthalate) following IPTG induction and cultures were incubated for $48 \mathrm{~h}$. Cell densities, glucose levels, limonene levels and perillyl alcohol production were then assessed.

\section{Fed-batch fermentation}

For $(R)-(+)$-perillyl alcohol production on a larger scale, fed-batch cultivations were performed in a $5 \mathrm{~L}$ bioreactor system (Biostat B plus MO $5 \mathrm{~L}$ ) using $2 \mathrm{~L}$ of fermentation fluid. Seed cultures $(100 \mathrm{ml}, 10 \mathrm{~g} \mathrm{NaCl}, 5 \mathrm{~g}$ yeast extract, and $10 \mathrm{~g}$ of tryptone per $1 \mathrm{~L}$ ) were added to shake flasks overnight at $37^{\circ} \mathrm{C}$ and Sparger aeration was performed to maintain high dissolved oxygen (DO) levels. Post-fermentation, the $\mathrm{pH}$ of the broth was maintained at 7.0 through ammonia addition. Fermentation was performed during the growth stages under the following conditions: $37^{\circ} \mathrm{C}$, agitation $400 \mathrm{rpm}$ and airflow at $1 \mathrm{~L} /$ min. Antifoam 204 was added as required. DO was maintained at $20 \%$ saturation through the control of air flow and stirrer speed (1-2 L/min and 400-900 rpm, respectively). When cells reached an $\mathrm{OD}_{600}$ of $\sim 20$, the temperature was switched to $30{ }^{\circ} \mathrm{C}$ and $0.2 \mathrm{mM}$ IPTG and $0.05 \mathrm{mM}$ riboflavin were added. DINP (10\%) was added after $4 \mathrm{~h}$ when the initial glucose levels were exhausted, as indicated by the increase in DO. The fed batch mode was initiated through the feeding of $60 \%$ glucose at appropriate rates. Residual glucose levels were maintained to low levels through the addition of acetic acid. Samples were periodically collected and $\mathrm{OD}_{600}$ values were determined prior to centrifugation for the separation of the organic and aqueous phases. Organic layers were removed for all GC-MS analysis.

\section{Analytical methods}

$E$. coli growth was determined through $\mathrm{OD}_{600}$ measurements on a spectrophotometer (Cary $50 \mathrm{UV}$-vis, Varian). The Shimadzu GC-MS system (TQ8050) was used for Limonene and perillyl alcohol identification. GC-MS conditions were as follows: $30 \mathrm{~m}$ DB-5MS column (internal diameter $0.32 \mathrm{~mm}$, film thickness $0.25 \mu \mathrm{m}$ ); temperature: $50^{\circ} \mathrm{C}$ hold, ramped up $10^{\circ} \mathrm{C} / \mathrm{min}$ to $250^{\circ} \mathrm{C}$ with a final hold at $250^{\circ} \mathrm{C}$ for $10 \mathrm{~min}$. Highly pure helium was used as a carrier at a linear velocity of $1 \mathrm{ml} /$ min; an injector temperature of $250^{\circ} \mathrm{C}$; a split ratio of 1 : 10; an ion source temperature of $230^{\circ} \mathrm{C}$ and mass range of $m / z 40-500$. Limonene and perillyl alcohol and perillaldehyde peaks were identified through the retention times of external standards and MS comparisons via the National Institute of Standards and Technology (NIST) database. Fermentation broths were mixed, centrifuged, and the organic layer was taken for GC-MS analysis.

The enantiomeric distribution of limonene was analyzed using the Agilent Technologies 7890B GC System on a Cyclodex B column $(30 \mathrm{~m} \times 0.25 \mathrm{~mm}$ internal diameter; film thickness $=0.25 \mu \mathrm{m})$. GC conditions were as follows: $50{ }^{\circ} \mathrm{C}$ hold, $2{ }^{\circ} \mathrm{C} / \mathrm{min}$ ramping to $160^{\circ} \mathrm{C}$; carrier: highpurity helium, linear velocity: $1 \mathrm{ml} / \mathrm{min}$; temperature of the injector: $250^{\circ} \mathrm{C}$; split ratio: $1: 20$. Compounds of interest: $(S)-(-)$-limonene at $21.2 \mathrm{~min}$ and $(R)-(+)$-limonene at $22.02 \mathrm{~min}$. The fermentation broth was mixed and centrifuged, and the organic layer was analyzed.

The concentration of mevalonate was determined by gas chromatography (GC) analysis on a Aglient19091J$413 \mathrm{HP}-5$ column $(30 \mathrm{~m} \times 0.32 \mathrm{~mm}$ internal diameter, film thickness $=0.25 \mu \mathrm{m}$ ). The broth was acidified to $\mathrm{pH}$ 2.0 with $3 \mathrm{M} \mathrm{HCl}$ and mixed with anhydrous $\mathrm{Na}_{2} \mathrm{SO}_{4}$. The mixture was extracted twice with ethylacetate. Mevalonate in the solvent layers was then analyzed by GC. GC conditions were as follows: $50{ }^{\circ} \mathrm{C}$ hold, $10^{\circ} \mathrm{C} /$ min ramping to $250^{\circ} \mathrm{C}$, hold $5 \mathrm{~min}$. Carrier: high-purity helium, linear velocity: $1 \mathrm{ml} / \mathrm{min}$; temperature of the injector: $260^{\circ} \mathrm{C}$.

Specific rotation of $(R)-(+)$-perillyl alcohol. The fermentation products were subjected to preparative TLC (PTLC) to isolate pure product [60]. Specific rotation was detected in the automatic polarimeter (JIAHANG). Test conditions: wavelength of sodium light $589 \mathrm{~nm}$, room temperature, length $10 \mathrm{~cm}, 1.8 \%(\mathrm{~W} / \mathrm{V})$ of $\mathrm{CHCl}_{3}$. Three times for each detection.

\section{Supplementary Information}

The online version contains supplementary material available at https://doi. org/10.1186/s12896-020-00662-7.

Additional file 1: Table S1. Strains and plasmids used in this study Table S2. Primers used in this study for plasmids construction. The restriction sites in the primers were underlined. Table S3. Primers for RTPCR used in this study. Fig. S1. Mevalonate and $(R)-(+)$-perillyl alcohol production engineered MVA pathway. The total production of MVA and $(R)$-(+)-perillyl alcohol was measured after $48 \mathrm{~h}$ of IPTG induction.

\section{Acknowledgements}

The authors appreciate the contribution of the Dr. Yujin Cao for his advice on strain design. The authors also acknowledge Cong Wang for the assistance on the conduction of GC-MS. 


\section{Authors' contributions}

CS, RZ and CX conceived and designed research. XD contributed analytical tools. CS performed experiments and analyzed data. CS wrote the manuscript. All authors read and approved the manuscript.

\section{Funding}

This work was supported by the National Natural Science of China (grant number 21878166), and the Taishan Scholar Project of Shandong Province, China (grant number ts201511033).

\section{Availability of data and materials}

The data supporting the conclusions of this article are included within the article.

\section{Ethics approval and consent to participate}

Not applicable.

\section{Consent for publication}

Not applicable.

\section{Competing interests}

The authors declare that they have no competing interests.

Received: 30 September 2020 Accepted: 8 December 2020 Published online: 08 January 2021

\section{References}

1. Peterson A, Bansal A, Hofman F, Chen TC, Zada G. A systematic review of inhaled intranasal therapy for central nervous system neoplasms: an emerging therapeutic option. J Neuro-Oncol. 2014;116(3):437-46.

2. Sundin T, Peffley D, Hentosh P. elF4E-overexpression imparts perillyl alcohol and rapamycin-mediated regulation of telomerase reverse transcriptase. Exp Cell Res. 2013;319(13):2103-12.

3. Sundin T, Peffley DM, Gauthier D, Hentosh P. The isoprenoid perillyl alcohol inhibits telomerase activity in prostate cancer cells. Biochimie. 2012;94(12): 2639-48.

4. Bindu PC, Jaisankar $P$, Hauer F, Gutzeit HO, Kundu SC. Biological relevance of host plant-derived terpenoid in the cocoons of the tropical tasar silkworm Antheraea mylitta. Biochem Syst Ecol. 2006;34(9):698-704.

5. Duetz WA, Bouwmeester H, Beilen JBV, Witholt B. Biotransformation of limonene by bacteria, fungi, yeasts, and plants. Appl Microbiol Biotechnol. 2003;61(4):269.

6. Paduch R, Kandefer-Szerszeń M, Trytek M, Fiedurek J. Terpenes: substances useful in human healthcare. Arch Immunol Ther Exp. 2007:55(5):315.

7. Wagner $\mathrm{KH}$, Elmadfa I. Biological relevance of terpenoids - overview focusing on mono-, di- and tetraterpenes. Ann Nutr Metab. 2003:47(3-4): 95-106

8. De Carvalho CCCR, Da Fonseca MMR. Biotransformation of terpenes. Biotechnol Adv. 2006;24(2):134-42.

9. Tranchida PQ, Zoccali M, Bonaccorsi I, Dugo P, Mondello L, Dugo G. The offline combination of high performance liquid chromatography and comprehensive two-dimensional gas chromatography-mass spectrometry: a powerful approach for highly detailed essential oil analysis. J Chromatogr A. 2013;1305(1):276-84

10. Lange BM. Biosynthesis and biotechnology of high-value p-Menthane Monoterpenes, including menthol, Carvone, and limonene. Adv Biochem Eng Biotechnol. 2015;148:319.

11. Beilen JB, Van RH, Daniel L, Ulrich B, Bernard W, Duetz WA. Biocatalytic production of perillyl alcohol from limonene by using a novel Mycobacterium sp. cytochrome P450 alkane hydroxylase expressed in Pseudomonas putida. Appl Environ Microbiol. 2005:71(4):1737.

12. CHANG HC, GAGE DA, ORIEL PJ. Cloning and expression of a limonene degradation pathway from Bacillus stearothermophilus in Escherichia coli. J Food Sci. 1995;60(3):551-3.

13. Mirata MA, Heerd D, Schrader J. Integrated bioprocess for the oxidation of limonene to perillic acid with Pseudomonas putida DSM 12264. Process Biochem. 2009;44(7):764-71.

14. Speelmans G, Bijlsma A, Eggink G. Limonene bioconversion to high concentrations of a single and stable product, perillic acid, by a solventresistant Pseudomonas putida strain. Appl Microbiol Biotechnol. 1998;50(5): 538-44.
15. Willrodt C, Halan B, Karthaus L, Rehdorf J, Julsing MK, Buehler K Schmid A. Continuous multistep synthesis of perillic acid from limonene by catalytic biofilms under segmented flow. Biotechnol Bioeng. 2017; 114(2):281-90.

16. Mars A, Gorissen J, van den Beld I, Eggink G. Bioconversion of limonene to increased concentrations of perillic acid by Pseudomonas putida GS1 in a fed-batch reactor. Appl Microbiol Biotechnol. 2001;56(1):101-7.

17. Trytek M, Fiedurek J, Skowronek M. Biotransformation of $(R)-(+)$-limonene by the Psychrotrophic Fungus Mortierella minutissima in $\mathrm{H}_{2} \mathrm{O}_{2}$-oxygenated culture. Food Technol Biotechnol. 2009;47(2):131-6.

18. Oliveira BHd, Strapasson RA. Biotransformation of the monoterpene, limonene, by Fusarium verticilloides. Braz Arch Biol Technol. 2000;43:0-0.

19. Menéndez $P$, García $C$, Rodríguez $P$, Moyna $P$, Heinzen $H$. Enzymatic systems involved in D-limonene biooxidation. Braz Arch Biol Technol. 2002;45:111-4.

20. Noma Y, Yamasaki S, Asakawa Y. Biotransformation of limonene and related compounds by Aspergillus cellulosae. Phytochemistry. 1992;31(8):2725-7.

21. Chang HC, Gage DA, Oriel PJ. Cloning and expression of a limonene degradation pathway from Bacillus stearothermophilus in Escherichia coli. J Food Sci. 2010;60(3):551-3.

22. Cheng S, Liu X, Jiang G, Wu J. Zhang J-I, lei D, Yuan Y-J, Qiao J, Zhao G-R: orthogonal engineering of biosynthetic pathway for efficient production of limonene in Saccharomyces cerevisiae. ACS Synth Biol. 2019;8(5):968-75.

23. Anthony J, Anthony L. F, kwon G, Newman J, Keasling J: optimization of the mevalonate-based isoprenoid biosynthetic pathway in Escherichia coli for production of the anti-malarial drug precursor amorpha-4,11-diene. Metab Eng. 2009;11(1):13-9.

24. Liu X-B, Liu M, Tao X-Y, Zhang Z-X, Wang F-Q, Wei D-Z. Metabolic engineering of Pichia pastoris for the production of dammarenediol-II. J Biotechnol. 2015;216:47-55.

25. Martin, Pitera DJ, Withers ST, Newman JD, Keasling JD. Engineering a mevalonate pathway in Escherichia coli for production of terpenoids. Nat Biotechnol. 2003;21(7):796-802.

26. Peraltayahya PP, Ouellet M, Chan R, Mukhopadhyay A, Keasling JD, Lee TS Identification and microbial production of a terpene-based advanced biofuel. Nat Commun. 2011;2(1):483.

27. Trikka FA, Nikolaidis A, Athanasakoglou A, Andreadelli A, Ignea C, Kotta K, Argiriou A, Kampranis SC, Makris AM. Iterative carotenogenic screens identify combinations of yeast gene deletions that enhance sclareol production. Microb Cell Factories. 2015;14(1):60.

28. Wu J, Cheng S, Cao J, Qiao J, Zhao G-R. Systematic optimization of limonene production in engineered Escherichia coli. J Agric Food Chem. 2019;67(25):7087-97.

29. Yoon S-H, Lee S-H, Das A, Ryu H-K, Jang H-J, Kim J-Y, Oh D-K, Keasling JD, Kim S-W. Combinatorial expression of bacterial whole mevalonate pathway for the production of $\beta$-carotene in E. coli. J Biotechnol. 2009;140(3):218-26.

30. Carter OA, Peters RJ, Croteau R. Monoterpene biosynthesis pathway construction in Escherichia coli. Phytochemistry. 2003:64(2):425-33.

31. Reiling KK, Yoshikuni Y, Martin VJJ, Newman J, Bohlmann J, Keasling JD. Mono and diterpene production in Escherichia coli. Biotechnol Bioeng. 2004 87(2):200-12

32. Alonso-Gutierrez J, Chan R, Batth TS, Adams PD, Keasling JD, Petzold CJ, Lee TS. Metabolic engineering of Escherichia coli for limonene and perillyl alcohol production. Metab Eng. 2013;19(Complete):33-41.

33. Yang J, Zhao G, Sun Y, Zheng Y, Jiang X, Liu W, Xian M. Bio-isoprene production using exogenous MVA pathway and isoprene synthase in Escherichia coli. Bioresour Technol. 2012;104:642-7.

34. Lücker J, El Tamer MK, Schwab W, Verstappen FWA, van der Plas LHW, Bouwmeester HJ, Verhoeven HA. Monoterpene biosynthesis in lemon (Citrus limon). Eur J Biochem. 2002;269(13):3160-71.

35. Kurusu T, Kuchitsu K, Tada Y. Plant signaling networks involving $\mathrm{Ca}^{2+}$ and Rboh/Nox-mediated ROS production under salinity stress. Front Recent Dev Plant Sci. 2015;6(427):427.

36. Paul E, Kimberly G. Synthesis of (+)-perillyl alcohol from (+)-limonene. In: Tetrahedron Letters the International Journal for the Rapid Publication of Preliminary Commun Org Chem; 2014.

37. Cornelissen S, Julsing MK, Volmer J, Riechert O, Schmid A, Bühler B. Wholecell-based CYP153A6-catalyzed (S)-limonene hydroxylation efficiency depends on host background and profits from monoterpene uptake via AlkL. Biotechnol Bioeng. 2013;110(5):1282-92.

38. Dahl RH, Zhang F, Alonso-Gutierrez J, Baidoo E, Batth TS, Redding-Johanson AM, Petzold CJ, Mukhopadhyay A, Lee TS, Adams PD, et al. Engineering 
dynamic pathway regulation using stress-response promoters. Nat Biotechnol. 2013;31:1039.

39. Sivy $T L$, Ray F, Rosenstiel TN. Evidence of isoprenoid precursor toxicity in Bacillus subtilis. Biosci Biotechnol Biochem. 2011;75(12):2376-83.

40. Cao Y, Zhang R, Liu W, Zhao G, Niu W, Guo J, Xian M, Liu H. Manipulation of the precursor supply for high-level production of longifolene by metabolically engineered Escherichia coli. Sci Rep. 2019;9(1):95.

41. Zheng G, Dan X, Abdallah II, Dijkshoorn L, Setroikromo R, Lv G, Quax WJ. Metabolic engineering of Bacillus subtilis for terpenoid production. Appl Microbiol Biotechnol. 2015;99(22):9395-406.

42. Griffin S, Wyllie SG, Markham J. Determination of octanol-water partition coefficient for terpenoids using reversed-phase high-performance liquid chromatography. J Chromatogr A. 1999;864(2):221-8.

43. Chang HC, Oriel P. Bioproduction of Perillyl alcohol and related Monoterpenes by isolates of Bacillus stearothermophilus. J Food Sci. 2010; 59(3):660-2.

44. Chubukov V, Mingardon F, Schackwitz W, Baidoo EE, Alonsogutierrez J, Hu Q, Lee TS, Keasling JD, Mukhopadhyay A. Acute limonene toxicity in Escherichia coli is caused by limonene-hydroperoxide and alleviated by a point mutation in alkyl hydroperoxidase (AhpC). Appl Environ Microbiol. 2015;81(14):4690-6.

45. Ma SM, Garcia DE, Redding-Johanson AM, Friedland GD, Rossana C, Batth TS, Haliburton JR, Dylan C, Keasling JD, Petzold CJ. Optimization of a heterologous mevalonate pathway through the use of variant HMG-COA reductases. Metab Eng. 2011;13(5):588-97.

46. Yang J, Xian M, Su S, Zhao G, Nie Q, Jiang X, Zheng Y, Liu W. Enhancing Production of Bio-Isoprene Using Hybrid MVA Pathway and Isoprene Synthase in E. coli. PLoS One. 2012;7(4):e33509.

47. Guo J, Cao Y, Liu H, Zhang R, Xian M, Liu H. Improving the production of isoprene and 1,3-propanediol by metabolically engineered Escherichia coli through recycling redox cofactor between the dual pathways. Appl Microbiol Biotechnol. 2019;103(6):2597-608.

48. Jongedijk E, Cankar K, Ranzijn J, van der Krol S, Bouwmeester H, Beekwilder $J$. Capturing of the monoterpene olefin limonene produced in Saccharomyces cerevisiae. Yeast. 2015;32(1):159-71.

49. Leng C, Kish JD, Kelley J, Mach M, Hiltner J, Zhang Y, Liu Y. Temperaturedependent Henry's law constants of atmospheric organics of biogenic origin. J Phys Chem A. 2013:117(40):10359-67.

50. Kiyota H, Okuda Y, Ito M, Hirai MY, Ikeuchi M. Engineering of cyanobacteria for the photosynthetic production of limonene from $\mathrm{CO}_{2}$.J Biotechnol. 2014;185:1-7.

51. Vararu F, Morenogarcia J, Moreno J, Niculaua M, Nechita B, Zamfir C, Colibaba C, Dumitru GD, Cotea W. Minor volatile compounds profiles of 'Aligoté' wines fermented with different yeast strains. Not Sci Biol. 2015;7(1):123-8.

52. Davies FK, Work VH, Beliaev AS, Posewitz MC. Engineering Limonene and Bisabolene Production in Wild Type and a Glycogen-Deficient Mutant of Synechococcus sp. PCC 7002. Front Bioeng Biotech. 2014;2:21.

53. Willrodt C, David C, Cornelissen S, Bühler B, Julsing MK, Schmid A. Engineering the productivity of recombinant Escherichia coli for limonene formation from glycerol in minimal media. Biotechnol J. 2014;9(8):1000-12.

54. Pang Y, Zhao Y, Li S, Zhao Y, Li J, Hu Z, Zhang C, Xiao D, Yu A. Engineering the oleaginous yeast Yarrowia lipolytica to produce limonene from waste cooking oil. Biotechnol Biofuels. 2019;12:241

55. Cao X, Lv Y-B, Chen J, Imanaka T, Wei L-J, Hua Q. Metabolic engineering of oleaginous yeast Yarrowia lipolytica for limonene overproduction. Biotechnol Biofuels. 2016;9(1):214.

56. Zhou J, Wang C, Yang L, Choi E-S, Kim S-W. Geranyl diphosphate synthase: an important regulation point in balancing a recombinant monoterpene pathway in Escherichia coli. Enzym Microb Technol. 2015;68:50-5.

57. Misook L. Effects of Glucose and Acetic Acid on the Growth of Recombinant E.coli and the Production of Pyruvate Dehydrogenase Complex-E2 Specific Human Monoclonal Antibody. Korean J Biotechnol Bioeng. 2000;15(5):482-48.

58. Zheng Y, Liu Q, Li L, Qin W, Yang J, Zhang H, Jiang X, Cheng T, Liu W, Xu X, et al. Metabolic engineering of Escherichia coli for high-specificity production of isoprenol and prenol as next generation of biofuels. Biotechnol Biofuels. 2013;6(1):57.

59. Brennan TCR, Turner CD, Krömer JO, Nielsen LK. Alleviating monoterpene toxicity using a two-phase extractive fermentation for the bioproduction of jet fuel mixtures in Saccharomyces cerevisiae. Biotechnol Bioeng. 2012; 109(10):2513-22
60. Chatterjee T, Bhattacharyya D. Biotransformation of limonene by Pseudomonas putida. Appl Microbiol Biotechnol. 2001;55(5):541-6.

\section{Publisher's Note}

Springer Nature remains neutral with regard to jurisdictional claims in published maps and institutional affiliations.
Ready to submit your research? Choose BMC and benefit from:

- fast, convenient online submission

- thorough peer review by experienced researchers in your field

- rapid publication on acceptance

- support for research data, including large and complex data types

- gold Open Access which fosters wider collaboration and increased citations

- maximum visibility for your research: over $100 \mathrm{M}$ website views per year

At BMC, research is always in progress.

Learn more biomedcentral.com/submissions 